\title{
The urban and rural capybaras (Hydrochoerus hydrochaeris) as reservoir of Salmonella in the western Amazon, Brazil ${ }^{1}$
}

\author{
Itacir O. Farikoski ${ }^{2 *}$ (D), Luciana S. Medeiros ${ }^{2}$, Yuri K. Carvalho ${ }^{2}$, David A. Ashford ${ }^{3}$, \\ Eduardo E. S. Figueiredo ${ }^{4}$, Dandara V.G.S. Fernandes ${ }^{4}$, Paula J.B. Silva ${ }^{2}$ \\ and Vânia M.F. Ribeiro ${ }^{2}$
}

\begin{abstract}
Farikoski I.O., Medeiros L.S., Carvalho Y.K., Ashford D.A., Figueiredo E.E.S., Fernandes D.V.G.S., Silva P.J.B. \& Ribeiro V.M.F. 2019. The urban and rural capybaras (Hydrochoerus hydrochaeris) as reservoir of Salmonella in the western Amazon, Brazil. Pesquisa Veterinária Brasileira 39(1):66-69. Programa de Pós-Graduação em Sanidade e Produção Animal Sustentável da Amazônia Ocidental, Universidade Federal do Acre, Rodovia BR-364 Km 4, Distrito Industrial, Rio Branco, AC 69915-900, Brazil. E-mail: itacir.farikoski@gmail.com

The capybara (Hydrochoerus hydrochaeris) is the largest rodent in the world. In the state of Acre, Brazil, populations of capybaras have been increasing significantly. The role of capybaras in the transmission of certain bacterial zoonotic infections is not well understood, including bacteria of the genus Salmonella. Salmonella spp. generally cause enteritis or septicemia in mammals, however many mammalian species can carry the bacteria asymptomatically and shed it in their feces. To better understand the possible role of capybaras as reservoirs of Salmonella spp., we conducted a study of Salmonella within fecal samples from capybara in Acre. In a convenience sample, 54 capybaras from two urban and two rural areas of Acre were captured and kept for three to four days for sampling. None of the animals were symptomatic of any intestinal illness. Three separate fecal samples were collected from each animal, during their stays in captivity. Each sample was cultured for the presence of Salmonella spp. at the bacteriology laboratory of the Veterinary College of the Federal University of Acre. Samples were seeded in tetrationate pre-enrichment broth and in pre-enrichment broth peptone. After a 24 hour of incubation all samples were streaked on MacConkey Agar (MC) and Salmonella-Shigella Agar (SS). Suggestive colonies were submitted to biochemical analysis. Salmonella compatible colonies according to biochemical profile were submitted to serotyping (Sorokit for Salmonella - Probac do Brasil). In addition, the first sample from each of the 54 capybara was tested for Salmonella spp. using PCR targeting gene hilA. Eight (5\%) of the 162 samples examined by bacterial culture were positive for Salmonella spp., while four (7\%) of the 54 examined by PCR were positive. From the eight positive animals on culture, five were from urban area and three from rural area. On PCR, only one positive animal was from urban area and four were from rural area. Overall, by either test, one of the 54 animals was positive. All samples were collected in free - living animals with no apparent clinical signs of salmonellosis, indicating the potential of capybara as reservoir on this ecosystem.
\end{abstract}

INDEX TERMS: Capybaras, Hydrochoerus hydrochaeris, Salmonella, Amazon, Brazil, zoonosis, wild animals.

\footnotetext{
${ }^{1}$ Received on July $5,2018$.

Accepted for publication on August 10, 2018.

${ }^{2}$ Post-Graduate Program in Sanitation and Sustainable Animal Production of the Western Amazon (PPGESPA), Universidade Federal do Acre (UFAC), Rodovia BR-364 Km 4, Distrito Industrial, Rio Branco, AC 69915-900, Brazil. *Corresponding author: itacir.farikoski@gmail.com

${ }^{3}$ The University of Kansas 1450 Jayhawk Blvd. Lawrence, KS 66045, United States of America.

${ }^{4}$ Laboratório de Microbiologia Molecular de Alimentos, Faculdade de Nutrição, Universidade Federal de Mato Grosso (UFMT), Av. Fernando Correa da Costa 2.367, Boa Esperança, Cuiabá, MT 78060-900, Brazil.
}

RESUMO.- [As capivaras urbanas e rurais (Hydrochoerus hydrochaeris) como reservatório de Salmonella no oeste da Amazônia, Brasil.] A capivara (Hydrochoerus hydrochaeris) é o maior roedor do mundo. No estado do Acre, Brasil, as populações de capivaras têm aumentado significativamente. O papel das capivaras na transmissão de certas infecções zoonóticas bacterianas não é bem compreendido, incluindo as bactérias do gênero Salmonella. Salmonella spp. geralmente causam enterite ou septicemia em mamíferos, porém muitas 
espécies de mamíferos podem carregar a bactéria de forma assintomática e eliminá-la em suas fezes. Para entender melhor o possível papel das capivaras como reservatórios de Salmonella spp., realizamos um estudo para identificação de Salmonella spp. em amostras fecais de capivaras no Acre. Em uma amostra de conveniência, 54 capivaras de duas áreas urbanas e duas áreas rurais do Acre foram capturadas e mantidas por três a quatro dias para amostragem. Nenhum dos animais era sintomático de qualquer doença intestinal. Três amostras fecais foram coletadas de cada animal, durante sua permanência em cativeiro. Cada amostra foi cultivada para a presença de Salmonella spp. no Laboratório de Bacteriologia Veterinária da Universidade Federal do Acre. As amostras foram semeadas em caldo de pré-enriquecimento tetrationato e em peptona de caldo de pré-enriquecimento. Após 24 horas de incubação, todas as amostras foram semeadas em ágar MacConkey (MC) e ágar Salmonella-Shigella (SS). Colônias sugestivas foram submetidas a análises bioquímicas. Colônias compatíveis com Salmonella de acordo com o perfil bioquímico foram submetidas à sorotipagem (Sorokit para Salmonella - Probac do Brasil). Além disso, a primeira amostra de cada uma das 54 capivaras foi testada para Salmonella spp. usando PCR, visando gene hilA. Oito (5\%) das 162 amostras examinadas por cultura bacteriana foram positivas para Salmonella spp. Enquanto quatro (7\%) das 54 examinadas pela PCR foram positivas. Dos oito animais positivos em cultura, cinco eram de área urbana e três de área rural. Na PCR, apenas um animal positivo era de área urbana e quatro de área rural. Considerando o diagnóstico conjunto por ambos os testes, PCR e cultura, um animal foi considerado positivo. Todas as amostras foram coletadas em animais livres, sem sinais clínicos aparentes de salmonelose, indicando o potencial da capivara como reservatório nesse ecossistema.

TERMOS DE INDEXAÇÃO: Capivaras urbanas e rurais, Hydrochoerus hydrochaeris, Salmonella, Amazônia, Brasil, zoonoses, animais silvestres.

\section{INTRODUCTION}

Capybaras (Hydrochoerus hydrochaeris), family Caviidae and subfamily Hidrochoerinae, are the largest rodents in the world and can be found in most of the South American continent, excluding only the more arid basins (Hosken \& Silveira 2002, Oliveira \& Bonvicino 2011). Capybara lives in close proximity to humans, within their range, and often come in contact with domestic animals and people. Capybaras may have an important role in the transmission of zoonotic etiological agents (Chiacchio et al. 2014), and reports on bacterial zoonotic diseases among wild animals are scarce and usually based only on serologic surveys (Nogueira \& Cruz 2007, Siembieda et al. 2011).

The global burden of nontyphoidal Salmonella gastroenteritis has been estimated to be 93,8 million cases of gastroenteritis each year, with 155,000 deaths (Majowicz et al. 2010). Lower mammals play a critical role in the maintenance and transmission of Salmonella spp. to humans, primarily in foodborne transmission. Wild animals can serve as a direct source of Salmonella infection for humans through contact with fecal contamination or through the secondary infection of domestic animals from wild animal sources. While capybara may be a source of zoonoses, there are only two reports of Salmonella were recorded in capybara (Bandarra et al. 1995, Nogueira
1998). In both cases the capybaras had been in captivity for several years. Only one study has previously been conducted on the Salmonella carriage rates of free-ranging capybara (Chiacchio et al. 2014).

PCR is an efficient technique for the diagnosis of Salmonella. It can be used to replace blood culture, but for a precise diagnosis a standard technique must be ensured in order to avoid false negatives (Sánchez-Jiménez \& Cardona-Castro 2004). In order to correct this problem, it is necessary to use enrichment broths that reduce these inhibitors (Pathmanathan et al. 2003). PCR using hILA gene is an important tool for the identification of Salmonella spp., additionally the use of multiplex PCR allows to differentiate some serovars (Kim et al. 2006, Crăciunaş et al. 2012).

To better understand the role of capybaras on spread of Salmonella spp., we conducted a study with a convenience sample of free ranging capybara from both urban and rural settings in the state of Acre, Brazil.

\section{MATERIALS AND METHODS}

Capybara sample. The study was conducted from June 2014 to November 2015. During this period, capybaras were captured in a convenience sample from free roaming herds in two urban areas and two rural areas. The two urban areas included the Federal University of Acre campus, UFAC ( $9^{\circ} 57^{\prime} 33.0^{\prime \prime}$ S 67 $\left.52^{\circ} 23.3^{\prime \prime} \mathrm{W}\right)$ and at Farmhouse Ipê (957'51.4" S 6752'14,9” W), a closed urban housing area made up of condominiums and about 100 families. The two rural areas were the Farm São Raimundo (0956'49.7" S 6744'9.4” W) and the Farm Piracema (1000'39.7" S 6756'14.9”'W).

After the capture, all the animals were identified with microchip and transported to the Catuaba Experimental Farm, located in the municipality of Senador Guiomard, Acre (10³'42.6” S 67³6'7.3” W) for further study. After completion of the study, the animals were released unharmed at the initial sites of their capture.

All animals were captured and anesthetized according to the protocol approved by CEUA/UFAC No. 23107.016723/2014-41. The capture and collection of samples of Brazilian wildlife was authorized by the Chico Mendes Institute for Biodiversity Conservation (ICMBIO) through the System of Authorization and Information on Biodiversity (SISBIO) No. 44791-1.

Collection of fecal samples. Each animal was sampled at the time of capture and then at day six and day 12 of captivity. Each fecal sample was collected using two sterile swabs per animal. The swabs were introduced rectally and rotated so as to cover the whole surface of the swab with animal feces. After the collection, the materials were labeled, kept chilled $\left(4^{\circ} \mathrm{C}\right)$, and transported to the Veterinary Bacteriology laboratory of the Federal University of Acre. All samples were processed for culture in less than 12 hours following collection. As a result of duplicating samples at each time of sampling, there were a total of 324 fecal samples taken for analysis from a total of 54 animals.

Sample processing. Of the 162 fecal samples collected, one of each sample was seeded in replicate on tetrationate pre-enrichment broth and on pre-enrichment broth peptone. After a 24 hour of incubation all samples were streaked on MacConkey Agar (MC) and Salmonella-Shigella Agar (SS) as shown below and incubated in at $37^{\circ} \mathrm{C}$, with readings at 24 and 48 hours.

After incubation for 24-48 hours, the morphologically suggestive colonies of Salmonella spp., production of hydrogen sulphide $\left(\mathrm{H}_{2} \mathrm{~S}\right)$ and no fermentation of lactose, were plated onto a blood agar plate and incubated at $37^{\circ} \mathrm{C}$ for a further 24 hours. After growth on blood 
agar, colonies were submitted to biochemical analysis. The following parameters were evaluated: bacterial motility, lysine decarboxylase production, glucose fermentation in depth and sucrose on the surface of the medium, production of hydrogen sulphide $\left(\mathrm{H}_{2} \mathrm{~S}\right)$, gas production, and use of the amino acid L-tryptophan (deamination), hydrolysis of Urea and the formation of indole (Quinn et al. 1994, Koneman et al. 2005). TSI-Triple Sugar Iron Agar was used to verify the fermentation of glucose, lactose and sucrose. Salmonella compatible colonies according to biochemical profile were submitted to serotyping, according the Kauffmann-White classification, (Sorokit for Salmonella - Probac do Brasil) using somatic (O) and flagellar $(\mathrm{H})$ sera to identify the most frequent serogroups and the most clinically significant serotypes according to the manufacturer 's specifications (Wattiau et al. 2011).

Polymerase chain reaction (PCR). A $2 \mathrm{ml}$ aliquot of tetrathionate (TT) broth from each of the 162 samples was frozen at $-4^{\circ} \mathrm{C}$ for detection of Salmonella spp. by PCR. Colonies with a biochemical profile compatible with Salmonella spp. were stored in glycerol and skimmed milk powder and frozen according to Malik (1988) and Thompson (1987) and also submitted to PCR for confirmation.

The aliquots of $1 \mathrm{ml}$ of the TT broth and the sugestive isolated colonies were subjected to DNA extraction and purification with DNeasy ${ }^{\circledR}$ merican Food Kit (Qiagen ${ }^{\circledR}$ ), to the quantification of DNA by fluorometry with Qubit 2.0 (Invitrogen ${ }^{\circledR}$ ). PCR assays were performed in duplicate for amplification of the hILA gene with primers hILA 2-F (5'-CTGCCGCAGTGTTAAGGATA-3') and hILA 2-R (5'-CTGTCGCCTTAATCGCATGT-3'), with initial denaturation at $94^{\circ} \mathrm{C}$ for $5 \mathrm{~min}$, followed by 30 cycles of $94^{\circ} \mathrm{C}$ at $1 \mathrm{~min}, 58^{\circ} \mathrm{C}$ at $1 \mathrm{~min}, 72^{\circ} \mathrm{C}$ at $1 \mathrm{~min}$ and final extension at $72^{\circ} \mathrm{C}$ for $10 \mathrm{~min}$. Using a reaction mixture $5 \mu$ l of buffer (Invitrogen ${ }^{\circledR}$ ), $0.2 \mathrm{mM}$ dNTP Fermentas ${ }^{\circledR}$ ), $1.5 \mathrm{U}$ of recombinant Taq polymerase (Platinum ${ }^{\circledR}$ Taq-Invitrogen ${ }^{\circledR}$ ), $5 \mathrm{mM}$ $\mathrm{MgCl} 2$ (Invitrogen ${ }^{\circledR}$ ) and 25pMol of each primer (Invitrogen ${ }^{\circledR}$ ) with a final volume of $25 \mu \mathrm{L}$. Were analyzed by $1.5 \%$ ultrapure agarose gel electrophoresis and stained with GelRed ${ }^{\mathrm{TM}}$ for visualization of the 497 base pair (bp) confirmatory fragment of Salmonella spp.

Statistical analysis. The chi-square test was used to compare diagnostic methods. Differences were considered significant when $\mathrm{p}<0.05$.

\section{RESULTS}

Among the 162 fecal samples collected over three separate samplings of 54 capybaras, eight samples were positive for Salmonella spp. by culture. All eight of these samples grew Salmonella spp. that were positive by agglutination testing to $A$ and $E$, but all were negative to the flagellar agglutination test. Four of these eight came from the first sampling of the animals, two from the second sampling, and two from the third sampling. From the eight positive animals on culture, five were from urban area and three from rural area. One culture isolate, from urban area, was confirmed as Salmonella spp. by PCR.

In addition to one sample being positive by both PCR and culture, five additional samples were positive by PCR alone when examining the TT aliquots for DNA. One of the PCR positive animals (2\%) was from urban area animal and four (7\%) of positive animals was from a rural area. Thirteen of the 54 animals analyzed (24.07\%) presented positive results when considering the results of the culture and PCR together.

\section{DISCUSSION}

Capybara represents an important link between wild, urban and production animals in rural and urban areas of South America. In addition, the fact that Capybaras are well adapted to urban and suburban environments means that they represent an additional direct threat to humans for zoonotic pathogens. Considering this potential for infection and transmission, we conducted this study to confirm the possible role of capybara as a reservoir of Salmonella spp. Our study confirms that capybaras are potential reservoirs or sources of infection for salmonellosis, when considering the results of the culture and PCR together $24.07 \%$ presented positive results. This result is higher than that observed by Nogueira (1998), who investigated enterobacteria in capybaras and found $4.92 \%$ of animals bearing Salmonella spp. when only the conventional culture is used.

Nogueira (1998) identified a strain of Salmonella belem and two of Salmonella paratyphi B. The author used the conventional technique of isolation by bacterial culture and serology in peri-urban breeding animals. In this work the suspicion was raised that these animals may have been contaminated by handlers or visitors, due to the specificity of Paratyphi serovar. The non-agglutination of the samples obtained from free-living capybara when exposed to flagellar sera indicates that these strains were probably of lower pathogenic potential for man. However, according to Acha \& Szyfres (2001), excluding serotypes S. typhi, S. paratyphi $A$ and $S$. parathyphi $C$, which are unique to humans, all serotypes of Salmonella are considered to be zoonotic. We did not have achieved serovar identification nor pathogenicity assessments in our study to compare to these earlier publications.

The similar results obtained in the pre-enrichment culture with buffered peptone water and TT broth demonstrated efficacy and complementarity for the diagnosis of Salmonella spp. allowing the cultivation of eight suspected isolates. Among the isolates only one was confirmed by PCR. This result is not unexpected because several factors limit the efficiency of the PCR technique for detecting bacteria. Biological samples may be accompanied by artifacts that have inhibitors, reducing the efficacy of the technique. Among the artifacts we can mention blood, bile salts found in feces and some milk proteins (Al-Soud \& Rådström 1998). Thus, as the isolates from this study were cryopreserved using milk and glycerol, the presence of milk inhibitors may have resulted in a lower PCR efficiency.

PCR from enrichment broths showed a better result in the detection of Salmonella spp. when compared to bacteriological culture $(\mathrm{P}<0.05)$. The two techniques associated with repeat sampling make the diagnosis of Salmonella spp. more effective. Especially in asymptomatic animals as in the case of capybaras under study. Miller et al. (2008) observed intermittent elimination of Salmonella spp. in asymptomatic rhinoceroses. This was even more evident in this study because both the isolation and PCR were able to identify the presence of Salmonella spp. on different samples, increasing the joint diagnostic sensitivity in the group of animals studied.

Cohen et al. (1996) observed that positive samples in PCR were negative in culture; however the majority of the positive cultures were also positive in PCR. Although traditional techniques of culture and bacterial identification are used as official for analysis, it is fundamental to complement molecular techniques, since they present a higher sensitivity in a shorter 
time (Gandra et al. 2008). Samples from five animals that were PCR positive (samples from the TT broth) were not confirmed by bacteriological culture which may indicate different differentiated bacterial profiles. The absence of bacterial growth in samples with positive PCR can also be explained by the predilection that some bacterial strains present by specific cuture media, then it is expected that molecular methods detect as positive samples considered negative in bacterial isolation (Sugimoto et al. 2009).

Differences were also found on the isolation pattern between the urban and rural groups. More suggestive colonies of Salmonella spp. were recovered from animals from urban areas, while PCR was able to identify as positive more samples collected in the Rural Zone. This fact may indicate that these animals may be exposed to different strains, suggesting a different sensitivity in the identification of distinct strains in both techniques (Murray et al. 2014).

\section{CONCLUSION}

These findings confirm the importance of free living capybaras as potential carriers and disseminators of Salmonella spp. in urban and rural areas of Brasil.

Acknowledgments. - We thank the Acre Research Support Foundation (FAPAC) for financial assistance.

Conflict of interest statement. - The authors have no competing interests.

\section{REFERENCES}

Acha P.N. \& Szyfres B. 2001. Zoonoses and Communicable Diseases Common to Man and Animals. 3rd ed. Pan American Health Organization, Washington, p.241-273.

Al-Soud W.A. \& Râdström P. 1998. Capacity of nine thermostable DNA polymerases to mediate DNA amplification in the presence of PCR-inhibiting samples. Appl. Environ. Microbiol. 64(10):3748-3753. <PMid:9758794>

Bandarra Ê.P., Silva C.A., Longoni E. \& Uieda W. 1995. Septicemia por Salmonella sp. em capivara (Hydrochaeris hydrochaeris). Semina, Ciênc. Agrárias 16(1):153-155.

Chiacchio R.G., Prioste F.E., Vanstreels R.E., Knöbl T., Kolber M., Miyashiro S.I. \& Matushima E.R. 2014. Health evaluation and survey of zoonotic pathogens in free-ranging capybaras (Hydrochoerus hydrochaeris). J. Wildl. Dis. 50(3):496-504. <http://dx.doi.org/10.7589/2013-05-109> <PMid:24779462>

Cohen N.D., Martin L.J., Simpson R.B., Wallis D.E. \& Neibergs H.L. 1996. Comparison of polymerase chain reaction and microbiological culture for detection of Salmonellae in equine feces and environmental samples. Am. J. Vet. Res. 57(6):780-786. <PMid:8725799>

Crăciunaș C., Keul A.L., Flonta M. \& Cristea M. 2012. DNA-based diagnostic tests for Salmonella strains targeting hilA, agfA, spvC and sef genes. J. Environ. Management 95(Suppl.):S15-S18. <http://dx.doi.org/10.1016/j. jenvman.2010.07.027><PMid:21071133>

Gandra E.Á., Gandra T.K.V., Mello W.S. \& Godoi H.D.S. 2008. Técnicas moleculares aplicadas à microbiologia de alimentos. Acta Scient. Technol. 30(1):109118. <http://dx.doi.org/10.4025/actascitechnol.v30i1.3245>

Hosken M.F. \& Silveira A.C. 2002. Criação de capivaras, p.8-25. In: Ibid. (Eds), Coleção Animais Silvestres. Vol.3. Aprenda Fácil, Viçosa, MG.
Kim S., Frye J.G., Hu J., Fedorka-Cray P.J., Gautom R. \& Boyle D.S. 2006. Multiplex PCR-based method for identification of common clinical serotypes of Salmonella enterica subsp. enterica. J. Clin. Microbiol. 44(10):3608-3615. <http://dx.doi.org/10.1128/JCM.00701-06> <PMid:16943358>

Koneman E.W., Allen S.D., Janda W.M., Schreckenberger P.C. \& Winn W.C. 2005. Diagnóstico Microbiológico: texto e atlas colorido. $5^{\mathrm{a}}$ ed. Medsi, Rio de Janeiro, p.189-272.

Majowicz S.E., Musto J., Scallan E., Angulo F.J., Kirk M., O’Brien S.J., Jones T.F., Fazil A., Hoekstra R.M. \& International Collaboration on Enteric Disease 'Burden of Illness' Studies. 2010. The global burden of nontyphoidal Salmonella gastroenteritis. Clin. Infect. Dis. 50(6):882-889. <http://dx.doi. org/10.1086/650733><PMid:20158401>

Malik K.A.1988. A new freeze-drying method for the preservation of nitrogenfixing and other fragile bacteria. J. Microb. Methods 8(5):259-271.<http:// dx.doi.org/10.1016/0167-7012(88)90008-5>

Miller M., Schille B. \& Pancake C. 2008. Salmonella surveillance in a herd of asymptomatic captive black rhinoceros (Diceros bicornis) using fecal culture and PCR. J. Zoo Wildl. Med. 39(1):56-60.<http://dx.doi.org/10.1638/20070001.1><PMid:18432096>

Murray P., Rosenthal K.S. \& Pfaller M.A. 2014. Microbiología Médica. $7^{a}$ ed. Elsevier, Rio de Janeiro, p.260-270.

Nogueira M.F. 1998. Avaliação da presença de Enterobacteriaceae, Aeromonas, Campylobacter e Cryptosporidium em fezes de capivara, Hydrochoerus hydrochaeris hydrochaeris (L. 1766), e determinação do perfil de susceptibilidade bacteriana frente a diferentes drogas. Master's Thesis, Faculdade de Medicina Veterinária e Zootecnia da Universidade Estadual Paulista, Botucatu, SP. 132p.

Nogueira M.F. \& Cruz T.F. 2007. Doenças da Capivara. Embrapa Pantanal, Corumbá, p.5-54.

Oliveira J.A. \& Bonvicino C.R. 2011. Ordem Rodentia: família Caviidae, p.386389. In: Reis N.R., Peracchi A.L., Pedro W.A. \& Lima I.P. (Eds), Mamíferos do Brasil. $2^{\mathrm{a}}$ ed. Universidade Estadual de Londrina, Londrina, PR.

Pathmanathan S.G., Cardona-Castro N., Sánchez-Jiménez M.M., Correa-Ochoa M.M., Puthucheary S.D. \& Thong K.L. 2003. Simple and rapid detection of Salmonella strains by direct PCR amplification of the hilA gene. J. Med. Microbiol. 52(Pt 9):773-776. <http://dx.doi.org/10.1099/jmm.0.051880><PMid:12909653>

Quinn M.E., Markey B.K., Leonard F.C., Carter M.E., Donnelly W.J. \& Leonard F.C. 1994. Clinical Veterinary Microbiology. Wolf Publishing, London, p.209-236.

Sánchez-Jiménez M.M. \& Cardona-Castro N. 2004. Validation of a PCR for diagnosis of typhoid fever and salmonellosis by amplification of the hilA gene in clinical samples from Colombian patients. J. Med. Microbiol. 53(Pt 9):875-878. <http://dx.doi.org/10.1099/jmm.0.45630-0><PMid:15314194>

Siembieda J.L., Kock R.A., Mccracken T.A. \& Newman S.H. 2011. The role of wildlife in transboundary animal diseases. Anim. Health Res. Revs 12(1):95111.<http://dx.doi.org/10.1017/S1466252311000041><PMid:21615975>

Sugimoto M., Wu J.Y., Abudayyeh S., Hoffman J., Brahem H., Al-Khatib K., Yamaoka Y. \& Graham D.Y. 2009. Unreliability of results of PCR detection of Helicobacter pylori in clinical or environmental samples. J. Clin. Microbiol. 47(3):738-742. <http://dx.doi.org/10.1128/JCM.01563-08> <PMid:19129407>

Thompson J.P. 1987. Cryopreservation of Azotobacteraceae in liquid nitrogen. J. Microbiol. Biotechnol. 3(3):323-336.

Wattiau P., Boland C. \& Bertrand S. 2011. Methodologies for Salmonella enterica subsp. enterica subtyping: gold standards and alternatives. Appl. Environ. Microbiol. 77(22):7877-7885. <http://dx.doi.org/10.1128/ AEM.05527-11><PMid:21856826>. 